\title{
Low temperature vibrational spectroscopy. III. Structural aspects and detection of phase transitions in crystalline alkali metal and tetramethylammonium hexabromotellurates and platinates
}

\section{Berg, Rolf W.}

Published in:

Journal of Chemical Physics

Link to article, DOI:

10.1063/1.438661

Publication date:

1979

Document Version

Publisher's PDF, also known as Version of record

Link back to DTU Orbit

Citation (APA):

Berg, R. W. (1979). Low temperature vibrational spectroscopy. III. Structural aspects and detection of phase transitions in crystalline alkali metal and tetramethylammonium hexabromotellurates and platinates. Journal of Chemical Physics, 71(6), 2531-2540. https://doi.org/10.1063/1.438661

\section{General rights}

Copyright and moral rights for the publications made accessible in the public portal are retained by the authors and/or other copyright owners and it is a condition of accessing publications that users recognise and abide by the legal requirements associated with these rights.

- Users may download and print one copy of any publication from the public portal for the purpose of private study or research.

- You may not further distribute the material or use it for any profit-making activity or commercial gain

- You may freely distribute the URL identifying the publication in the public portal 


\title{
Low temperature vibrational spectroscopy. III. Structural aspects and detection of phase transitions in crystalline alkali metal and tetramethylammonium hexabromotellurates and platinates
}

\author{
Rolf Willestofte Berg \\ Chemistry Department A, The Technical University of Denmark, Building 207, DK-2800 \\ Lyngby, Denmark \\ (Received 17 November 1978)
}

The low-frequency infrared and Raman spectra of $\mathrm{A}_{2}\left[\mathrm{TeBr}_{6}\right]$ with $\mathrm{A}=\mathrm{K}, \mathrm{Rb}, \mathrm{Cs}, \mathrm{NH}_{4},\left(\mathrm{CH}_{3}\right)_{4} \mathrm{~N}$, $\left(\mathrm{CD}_{3}\right)_{4} \mathrm{~N}$ and of $\mathrm{A}_{2}\left[\mathrm{PtBr}_{6}\right]$ with $\mathrm{A}=\mathrm{K},\left(\mathrm{CH}_{3}\right)_{4} \mathrm{~N}$, and $\left(\mathrm{CD}_{3}\right)_{4} \mathrm{~N}$ were recorded as a function of temperature down to $\sim 100 \mathrm{~K}$. The spectra of the $\mathrm{Rb}$ and $\mathrm{Cs}$ compounds changed little. For the other salts new, and in some cases sharp, bands were observed at low temperatures. The spectra have been assigned, and in most cases a confirmation of previous results was obtained. The assignment ambiguity in the literature on the $\nu_{4}$ mode of $\left[\mathrm{PtBr}_{6}\right]^{2-}$ has been solved, placing it at $\sim 130 \mathrm{~cm}^{-1}$. The majority of the new low temperature bands were interpreted in accordance with the known occurrence of phase transitions breaking the ideal antifluorite $\mathrm{K}_{2}\left[\mathrm{PtCl}_{6}\right]$-type symmetry, but it appears that the method of vibrational spectroscopy does not invariably reflect the presence of phases of lower symmetry. In the spectra of the tetramethylammonium compounds, methyl torsional IR bands were observed with increasing sharpness at lower temperatures. This behavior can be correlated with a gradual ordering of methyl torsional disorder. The potential energy barrier against methyl group rotation was found to be of the order $4-5 \mathrm{kcal} / \mathrm{mol}$, showing that the methyl groups are not pseudo freely rotating. The anharmonicity of the vibrations in tetramethylammonium hexabromotellurate seems to increase abnormally at lower temperatures, possibly due to enhanced methyl-bromine interaction.

\section{INTRODUCTION}

The application of temperature dependent vibrational spectroscopy has proved to be a practicable way to detect new phase transitions in solids. Equipment for variable temperature spectroscopy is common nowadays, and exploratory survey experiments can be quickly carried out using powder samples. We have previously used this approach ${ }^{1}$ to examine some hexachlorometallate (IV) salts. Having examined some hexachlorotellurates, -platinates, and -stannates at lower temperatures, we here consider as further examples simple hexabromotellurates and hexabromoplatinates $\mathrm{A}_{2}\left(\mathrm{MBr}_{6}\right)$, with $\mathrm{A}=\mathrm{K}$, $\left(\mathrm{CH}_{3}\right)_{4} \mathrm{~N}$, and $\left(\mathrm{CD}_{3}\right)_{4} \mathrm{~N}$ for $\mathrm{M}=\mathrm{Te}$ and $\mathrm{Pt}$, and $\mathrm{A}=\mathrm{Rb}, \mathrm{Cs}$, and $\mathrm{NH}_{4}$ for $\mathrm{M}=\mathrm{Te}$ only.

The tellurium bromides have previously been examined by $\mathrm{x}$-ray structural, ${ }^{2-5}{ }^{79} \mathrm{Br}$ nuclear quadrupole resonance, ${ }^{6}$ and ${ }^{125} \mathrm{Te}$ Mössbauer ${ }^{7}$ methods. The NQR data ${ }^{6}$ indicated nonequivalent bromine atoms for monoclinic $\mathrm{K}_{2}\left(\mathrm{TeBr}_{6}\right)$ crystals already at room temperature and for $\left(\mathrm{NH}_{4}\right)_{2}\left(\mathrm{TeBr}_{6}\right)$ below $-52^{\circ} \mathrm{C}$, whereas the $\mathrm{Cs}$ and $\left(\mathrm{CH}_{3}\right)_{4} \mathrm{~N}$ salts have equivalent bromine atoms at room temperature and down to liquid-nitrogen temperature. For all $\mathrm{A}_{2}\left(\mathrm{TeBr}_{6}\right)$ compounds examined so far, no indication has been found of any Gillespie type distortion of the regular $\left(\mathrm{TeBr}_{6}\right)^{2-}$ octahedra due to the presence of the $5 s^{2}$ lone pair of electrons. We wanted to investigate whether such effects or phase transitions could be observed at low temperatures using IR and Raman spectroscopy. Furthermore, it has recently been shown by $\mathrm{x}$-ray diffraction ${ }^{8}$ that $\mathrm{Te}$ takes a $S_{6} \equiv \overline{3}$ site symmetry in the cubic $\left[\left(\mathrm{CH}_{3}\right)_{4} \mathrm{~N}\right]_{2}\left(\mathrm{TeBr}_{6}\right)$ crystals (space group $F d 3 c \equiv O_{h}^{8}, Z=32$ ), and an investigation of the influence of this lower symmetry on the spectra was a motivation for this study.
The $\mathrm{K}_{2}\left(\mathrm{PtBr}_{6}\right)$ compound has been investigated previously by several techniques, but this is not the case with $\left[\left(\mathrm{CH}_{3}\right)_{4} \mathrm{~N}\right]_{2}\left(\mathrm{PtBr}_{6}\right)$. At room temperature, $\mathrm{K}_{2}\left(\mathrm{PtBr}_{6}\right)$ has the cubic antifluorite structure. ${ }^{9-11}$ As the temperature is decreased, it exhibits several structural phase transitions. ${ }^{12-14}$ The influence of this complicated behavior on the vibrational spectra is unknown and hence we decided to investigate $\mathrm{K}_{2}\left(\mathrm{PtBr}_{6}\right)$. The tetramethylammonium hexabromoplatinate salts were included with the intention of comparing to the tellurates. The rubidium, cesium, and ammonium salts were left out, since they are known to remain cubic down to liquid-nitrogen temperature ${ }^{15,16}\left[\left(\mathrm{NH}_{4}\right)_{2}\left(\mathrm{PtBr}_{6}\right)\right.$ has a transition at $\left.58 \mathrm{~K}\right]$.

\section{STRUCTURES, SELECTION RULES, AND SPECTROSCOPIC WORK}

\section{A. $\mathrm{K}_{2}\left(\mathrm{TeBr}_{6}\right)$}

The room temperature structure of the potassium salt is accurately known ${ }^{2}$ (see Fig. 1). It is monoclinic $\left(P 2_{1} / n \equiv C_{2 h}^{5}, Z=2\right)$ due to small rotations of virtually undistorted $\left(\mathrm{TeBr}_{6}\right)^{2-}$ octahedra in a pseudo- $\mathrm{K}_{2}\left(\mathrm{PtCl}_{6}\right)$ antifluorite lattice, as also discussed in Ref. 1. At higher temperatures, a real $\mathrm{K}_{2}\left(\mathrm{PtCl}_{6}\right)$-type structure for $\mathrm{K}_{2}\left(\mathrm{TeBr}_{6}\right)$ probably exists; evidence of phase transitions at $\sim 405$ and $\sim 434 \mathrm{~K}$ has been found by differential thermal analysis, ${ }^{14}$ and perhaps a further transition takes place at $\sim 243 \mathrm{~K} .{ }^{6}$ However, based on $\mathrm{x}$-ray powder diffraction data, Fergusson and Heweldt ${ }^{5}$ claimed that $\mathrm{K}_{2}\left(\mathrm{TeBr}_{6}\right)$ was cubic at room temperature, but this is probably due to low accuracy (these authors apparently did not know Brown's single crystal results). ${ }^{2}$

The inf rared and Raman spectra of $\mathrm{K}_{2}\left(\mathrm{TeBr}_{6}\right)$ have been obtained at room temperature, ${ }^{17-22}$ and in IR at 


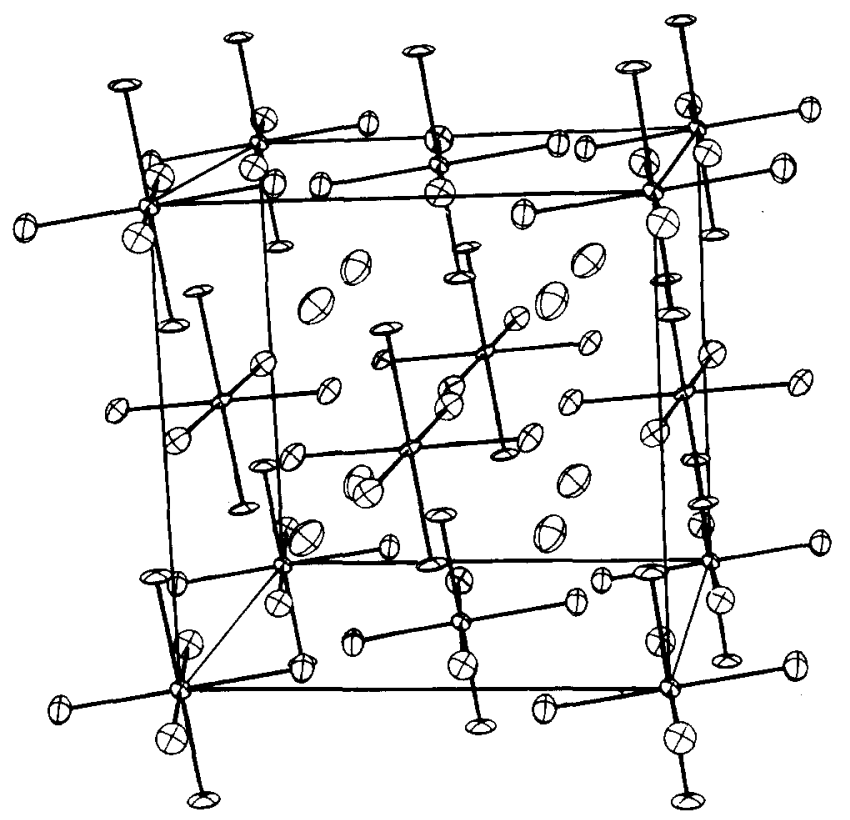

FIG. 1. The structure of $\mathrm{K}_{2}\left(\mathrm{TeBr}_{6}\right)$ as determined by Brown, ${ }^{2}$ showing an unconventional doubled cell which is most convenient when comparing wi th the $\mathrm{K}_{2}\left(\mathrm{PtCl}_{6}\right)$ standard structure.

$\sim 120 \mathrm{~K} .^{20}$ Selection rules (factor group analysis) based on the monoclinic structure are summarized in Table I.

\section{B. (Rb, Cs, $\left.\mathrm{NH}_{4}\right)_{2}\left(\mathrm{TeBr}_{6}\right)$}

These salts seem to crystallize in the $\mathrm{K}_{2}\left(\mathrm{PtCl}_{6}\right)$ lat tice. For $\mathrm{Rb}$, the evidence is less convincing (powder $\mathrm{x}$-ray, ${ }^{5}$ Mössbauer, ${ }^{7}$ IR, and Raman data ${ }^{19-21}$ ), but for $\mathrm{Cs}$, little doubt exists (single crystal ${ }^{3}$ and powder ${ }^{4.5}$ $x$-ray data and other kinds of evidence $\left.{ }^{6,7,18-21,23}\right)$. At room temperature, the ammonium salt has the same structure too. ${ }^{3,5}$ At lower temperatures, probably below $214 \mathrm{~K}$ [according to DTA (differential thermal analysis) $)^{14}$ ] or $221 \mathrm{~K}$ (according to NQR data ${ }^{6}$ ), another phase exists. The tetragonal space group $P 4 / m n c \equiv D_{4 h}^{6}$ (No. 128 with $Z=2$ ) was deduced from single crystal x-ray film data. ${ }^{3}$ The phase transition is reversible and there is evidence of yet a third phase at temperatures below $\sim 200 \mathrm{~K}\left(\mathrm{NQR}^{6}\right)$, or below $194 \mathrm{~K}\left(\mathrm{DTA}^{14}\right)$.

The selection rules resulting from the $\mathrm{K}_{2}\left(\mathrm{PtCl}_{6}\right)$ structure have often been given, e.g., in Ref. 1. For the $\left(\mathrm{NH}_{4}\right)_{2}\left(\mathrm{TeBr}_{6}\right)$ low temperature phase of $D_{4 h}^{6}$ symmetry,

TABLE I. Unit cell group analysis ${ }^{2}$ of $\mathrm{K}_{2}\left(\mathrm{TeBr}_{6}\right)$ of space group $C_{2 h}^{5}\left(\equiv P 2_{1} / n\right.$, No. $\left.14, Z=2\right)$. Te is on Wyckoff site $a$ (C $C_{i}$ symmetry); $\mathrm{Br}$ is on sites of type $C$ with no symmetry. ${ }^{2}$

\begin{tabular}{llllll}
\hline \hline$C_{2 h}$ symmetry & $T_{A}$ & $T^{\mathrm{b}}$ & $R\left(\mathrm{TeBr}_{6}\right)$ & $N_{i}\left(\mathrm{TeBr}_{6}\right)^{\mathrm{b}}$ & Activity in \\
\hline$A_{g}$ & & $3\left(\nu_{L 2}\right)$ & $3\left(\nu_{L 1}\right)$ & $6\left(\nu_{1}+2 \nu_{2}+3 \nu_{5}\right)$ & Raman \\
$B_{g}$ & & $3\left(\nu_{L 2}\right)$ & $3\left(\nu_{L 1}\right)$ & $6\left(\nu_{1}+2 \nu_{2}+3 \nu_{5}\right)$ & Raman \\
$A_{u}$ & 1 & $5\left(\nu_{L 3}\right)$ & & $9\left(3 v_{3}+3 \nu_{4}+3 \nu_{6}\right)$ & IR \\
$B_{u}$ & 2 & $4\left(\nu_{L 3}\right)$ & & $9\left(3 \nu_{3}+3 \nu_{4}+3 \nu_{6}\right)$ & IR \\
\hline \hline
\end{tabular}

${ }^{2} T_{A}=$ inactive acoustic, $T=$ optic-branch translatory, $R=$ rotatory, and $N_{i}=$ internal modes.

'The notation of the frequencies $v_{1}-v_{L 3}$ refers to those of $O_{h}$ symmetry. 1 they are less restrictive allowing for possible factor group doublings, splittings of the $\nu_{1}-\nu_{5}$ modes and $\nu_{6}$ IR activity.

\section{C. $\left[\left(\mathrm{CH}_{3}\right)_{4} \mathrm{~N}\right]_{2}\left(\mathrm{TeBr}_{6}\right)$}

This compound has a single ${ }^{79} \mathrm{Br}$ NQR line at room, dry ice, and liquid-nitrogen temperatures, ${ }^{6}$ but a powder $\mathrm{x}$-ray diffraction pattern quite different from that of a $\mathrm{K}_{2}\left(\mathrm{PtCl}_{6}\right)$ type structure. ${ }^{6}$ The compound was recently shown by single crystal $x$-ray diffractometr $y^{8}$ to have an eightfold increased cubic unit cell of space group $F d 3 c \equiv O_{h}^{8}$ (No. 228) with $Z=32$ and $a=26.563 \AA$. The $\left(\mathrm{TeBr}_{6}\right)^{2-}$ ion is rotated $9.1^{\circ}$ around $\{111\}$-type vectors and slightly deformed towards a flattened trigonal antiprism; the $2.700 \AA$ long $\mathrm{Te}-\mathrm{Br}$ bonds form angles $7.4^{\circ}$ with the cubic axes, and $89.2^{\circ}$ or $90.8^{\circ}$ with each other. There are two kinds of tetramethylammonium ions (Fig. 2). The deformation of $\left(\mathrm{TeBr}_{6}\right)^{2-}$ has nothing to do with the $5 s^{2}$ pair of electrons, since a similar deformation occurs in $\left[\left(\mathrm{CH}_{3}\right)_{4} \mathrm{~N}\right]_{2}\left(\mathrm{PtCl}_{6}\right)$.

The selection rules based on this structure are given in Table II. They predict a number of "factor group splittings" and IR activity of the formerly inactive $\nu_{6}$ bending mode of $\left(\mathrm{TeBr}_{6}\right)^{2-}$. The modes involving hydrogen are omitted except for the methyl torsions since we are primarily interested in the region below $600 \mathrm{~cm}^{-1}$ where the $\left(\mathrm{MX}_{6}\right)^{2-}$ and the external modes occur. It has been shown that the only internal modes of the tetramethylammonium ion occurring within this range are the $\mathrm{C}_{4} \mathrm{~N}$ skeletal deformations $\nu_{8}^{+}$and $\nu_{19}^{+}$and the methyl torsions $\nu_{4}^{+}$and $\nu_{12}^{+}$; and their approximate frequencies are known. ${ }^{24}$ Adams and Morris ${ }^{19}$ have obtained the room temperature spectra and assigned the $\left(\mathrm{TeBr}_{6}\right)^{2-}$ modes.

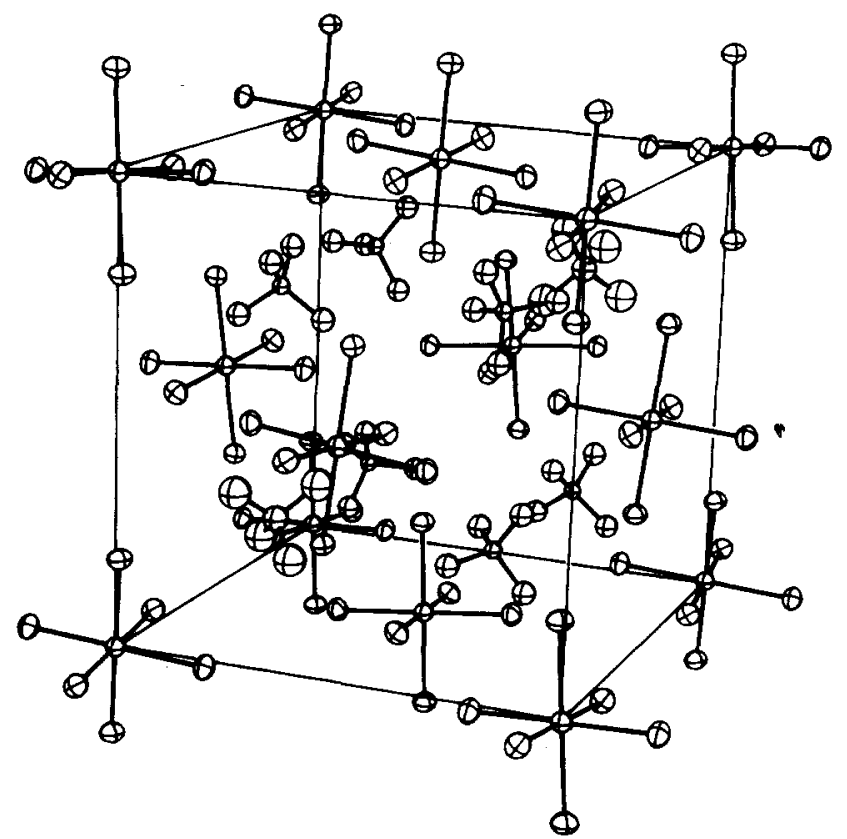

FIG. 2. The structure of $\left[\left(\mathrm{CH}_{3}\right)_{4} \mathrm{~N}\right]_{2}\left(\mathrm{TeBr}_{6}\right)$ as determined by Berg and Nielsen. ${ }^{8}$ Only $1 / 8$ of the full cell is depicted. 
TABLE II. Unit cell group analysis ${ }^{a}$ of $\left[\left(\mathrm{CH}_{3}\right)_{4} \mathrm{~N}_{2}\left(\mathrm{TeBr}_{6}\right)\right.$ of space group $O_{h}^{8}(\equiv F d 3 c$, No. 228, $Z=32$ ). Te is on Wyckoff site $c$ $\left(S_{6}\right.$ symmetry); $\mathrm{Br}$ is on site $h\left(C_{1}\right), \mathrm{N}$ on $a(T)$ and $d\left(S_{4}\right)$, and $\mathrm{C}$ on $e\left(C_{3}\right)$ and $h\left(C_{1}\right){ }^{8}$

\begin{tabular}{|c|c|c|c|c|c|c|c|c|}
\hline$O_{h}$ symmetry & $T_{A}$ & $T$ & $R\left(\mathrm{TeBr}_{6}\right)$ & $R\left(\mathrm{C}_{4} \mathrm{~N}\right)$ & $N_{i}\left(\mathrm{TeBr}_{6}\right)$ & $N_{i}\left(\mathrm{C}_{4} \mathrm{~N}\right)$ & Methyltors $^{\mathrm{b}}$ & Activity in \\
\hline$A_{1 g}$ & & & 1 & 1 & $2\left(\nu_{1}+\nu_{5}\right)$ & $3\left(\nu_{1}^{\prime}+\nu_{1}^{\prime \prime}+\nu_{2}^{\prime \prime}\right)$ & $2\left(v_{4}^{\prime}+v_{12}^{\prime \prime}\right)$ & Raman \\
\hline$A_{2 g}$ & & 1 & 1 & 0 & $2\left(v_{1}+v_{5}\right)$ & $4\left(\nu_{1}^{\prime}+\nu_{2}^{\prime \prime}+\nu_{3}^{\prime \prime}+v_{4}^{\prime \prime}\right)$ & $2\left(v_{4}^{\prime}+v_{4}^{\prime \prime}\right)$ & \\
\hline$E_{g}$ & & 1 & 2 & 1 & $4\left(2 \nu_{2}+2 \nu_{5}\right)$ & $7\left(2 v_{2}^{\prime}+\nu_{1}^{\prime \prime}+2 v_{2}^{\prime \prime}+\nu_{3}^{\prime \prime}+v_{4}^{\prime \prime}\right)$ & $2\left(v_{4}^{\prime \prime}+v_{12}^{\prime \prime}\right)$ & Raman \\
\hline$T_{1 g}^{g}$ & & 3 & 3 & 4 & $6\left(\nu_{1}+2 \nu_{2}+3 \nu_{5}\right)$ & $8\left(\nu_{3}^{\prime}+\nu_{4}^{\prime}+\nu_{1}^{\prime \prime}+\nu_{2}^{\prime \prime}+2 \nu_{3}^{\prime \prime}+2 \nu_{4}^{\prime \prime}\right)$ & $4\left(\nu_{12}^{\prime}+3 v_{12}^{\prime \prime}\right)$ & \\
\hline$T_{2 g}$ & & 4 & 3 & 3 & $6\left(\nu_{1}+2 \nu_{2}+3 \nu_{5}\right)$ & $9\left(\nu_{3}^{\prime}+\nu_{4}^{\prime}+\nu_{2}^{\prime \prime}+3 \nu_{3}^{\prime \prime}+3 v_{4}^{\prime \prime}\right)$ & $4\left(\nu_{12}^{\prime}+\nu_{4}^{\prime \prime}+2 \nu_{12}^{\prime \prime}\right)$ & Raman \\
\hline$A_{1 u}$ & & 2 & 0 & 0 & $3\left(\nu_{3}+\nu_{4}+\nu_{6}\right)$ & $4\left(\nu_{1}^{\prime}+\nu_{2}^{\prime \prime}+v_{3}^{\prime \prime}+v_{4}^{\prime \prime}\right)$ & $2\left(\nu_{4}^{\prime}+\nu_{4}^{\prime \prime}\right)$ & \\
\hline$A_{2 u}$ & & 1 & 0 & 1 & $3\left(\nu_{3}+v_{4}+\nu_{6}\right)$ & $3\left(\nu_{1}^{\prime}+\nu_{1}^{\prime \prime}+\nu_{2}^{\prime \prime}\right)$ & $2\left(v_{4}^{\prime}+v_{12}^{\prime \prime}\right)$ & \\
\hline$E_{u}$ & & 3 & 0 & 1 & $6\left(2 v_{3}+2 v_{4}+2 v_{6}\right)$ & $7\left(2 \nu_{2}^{\prime}+\nu_{1}^{\prime \prime}+2 \nu_{2}^{\prime \prime}+\nu_{3}^{\prime \prime}+\nu_{4}^{\prime \prime}\right)$ & $2\left(v_{4}^{\prime \prime}+v_{12}^{\prime \prime}\right)$ & \\
\hline$T_{1 u}$ & 1 & 6 & 0 & 3 & $9\left(3 v_{3}+3 v_{4}+3 v_{6}\right)$ & $9\left(\nu_{3}^{\prime}+\nu_{4}^{\prime}+\nu_{2}^{\prime \prime}+3 \nu_{3}^{\prime \prime}+3 \nu_{4}^{\prime \prime}\right)$ & $4\left(v_{12}^{\prime}+\nu_{4}^{\prime \prime}+2 \nu_{12}^{\prime \prime}\right)$ & IR \\
\hline$T_{2 u}$ & & 6 & 0 & 4 & $9\left(3 \nu_{3}+3 v_{4}+3 v_{6}\right)$ & $8\left(v_{3}^{\prime}+\nu_{4}^{\prime}+\nu_{1}^{\prime \prime}+v_{2}^{\prime \prime}+2 \nu_{3}^{\prime \prime}+2 v_{4}^{\prime \prime}\right)$ & $4\left(v_{12}^{\prime}+3 v_{12}^{\prime \prime}\right)$ & \\
\hline
\end{tabular}

${ }^{a}$ For explanation of symbols, see Table I. The distribution of the internal modes (Herzberg notation $\nu_{j}$ ) was obtained using the correlation approach. ' and " refers to tetramethylammonium ions on site $a$ and $d$, respectively.

${ }^{v_{4}}$ and $\nu_{12}$ modes of $\left(\mathrm{CH}_{3}\right)_{4} \mathrm{~N}$ are methyltorsions (see Ref. 17). Other hydrogen modes are left out because of their high frequencies.

\section{D. $\mathrm{K}_{2}\left(\mathrm{PtBr}_{6}\right)$}

Powder and single crystal $\mathrm{x}$-ray examinations have shown that $\mathrm{K}_{2}\left(\mathrm{PtBr}_{6}\right)$ has the $\mathrm{K}_{2}\left(\mathrm{PtCl}_{6}\right)$-type structure at room temperature. ${ }^{9-11}$ According to the temperature variation of the data for the ${ }^{79} \mathrm{Br} N Q R$ frequency and spin-lattice relaxation time, and data obtained by DTA, ${ }^{14}$ transitions occur in $\mathrm{K}_{2}\left(\mathrm{PtBr}_{6}\right)$ at $169,143,137,105$, and $78 \mathrm{~K}^{13}$ It seemed from the analysis ${ }^{13}$ of the experiments that the crystal becomes tetragonal (symmetry class $C_{4 h}$ ) in the range $169-143 \mathrm{~K}$, possibly due to some finite reorientation of undistorted $\left(\mathrm{PtBr}_{6}\right)^{2-}$ octahedra (perhaps $a \sim 7^{\circ}$ rotation $^{15}$ around one of the cubic axes). The structure of the phase obtained between 143 and $137 \mathrm{~K}$ has a still lower symmetry, whereas NQR and $\mathrm{x}$-ray results indicated a tetragonal structure again between 137 and $105 \mathrm{~K}^{13}$

The infrared and Raman spectra have been recorded and analyzed in several reports, ${ }^{10,25-30}$ in some cases as a function of pressure, ${ }^{31,32}$ but not as a function of temperature.

\section{E. $\left[\left(\mathrm{CH}_{3}\right)_{4} \mathrm{~N}\right]_{2}\left(\mathrm{PtBr}_{6}\right)$}

The structure is unknown but presumably analogous to that of the tellurium compound. Two phases of the compound have been reported, a cubic one at room temperature with a density of $2.402 \mathrm{~g} / \mathrm{cm}^{3}\left(18{ }^{\circ} \mathrm{C}\right)$ and another less symmetric one (pseudocubic) obtained at low temperatures in a polarizing microscope with liquid air cooling. ${ }^{33}$ To our knowledge, the vibrational spectra have not been recorded even at room temperature.

\section{EXPERIMENTAL}

The tellurium compounds were prepared $d^{34}$ by dissolving $\mathrm{TeO}_{2}$ in hot concentrated hydrobromic acid and adding $\mathrm{ABr}\left[\mathrm{A}=\mathrm{K}, \mathrm{Rb}, \mathrm{Cs},\left(\mathrm{CH}_{3}\right)_{4} \mathrm{~N},\left(\mathrm{CD}_{3}\right)_{4} \mathrm{~N}\right]$ dissolved in a minimum of water. The orange to red crystals were separated and washed with a minimum of cold conc. $\mathrm{HBr}$ and dried at $\sim 80^{\circ} \mathrm{C}$. The dark red platinum compounds were obtained from solutions of $\mathrm{H}_{2}\left(\mathrm{PtBr}_{6}\right)$ and $\mathrm{ABr}\left[\mathrm{A}=\mathrm{K},\left(\mathrm{CH}_{3}\right)_{4} \mathrm{~N}\right.$, and $\left.\left(\mathrm{CD}_{3}\right)_{4} \mathrm{~N}\right]$ by slow evaporation. \{Analyses by Volhard titration; $\mathrm{K}_{2} \mathrm{TeBr}_{6}: \mathrm{Br}-$ found $=68.8 \%$, calc $=69.97 \% ; \quad\left[\left(\mathrm{CH}_{3}\right)_{4}\right]_{2} \mathrm{TeBr}_{6}: \mathrm{Br}-$ found $=64.3 \%$, calc $=63.46 \%\}$. The techniques used in measuring the spectra have been described in detail. ${ }^{1}$ The Raman spectra were obtained on powders, using $\sim 20$ to $\sim 80 \mathrm{~mW}$ of the $647.1 \mathrm{~nm} \mathrm{Kr}{ }^{+}$laser line; the infrared spectra were calculated by Fourier transformation of interferograms, and care was exercised to determine the temperatures. ${ }^{1}$ The spectral resolution was $2-4$ $\mathrm{cm}^{-1}$.

\section{RESULTS AND DISCUSSION}

\section{A. General}

The spectra obtained for $\mathrm{K}_{2}\left(\mathrm{TeBr}_{6}\right), \mathrm{Cs}_{2}\left(\mathrm{TeBr}_{6}\right)$, and $\left[\left(\mathrm{CH}_{3}\right)_{4} \mathrm{~N}\right]_{2}\left(\mathrm{TeBr}_{6}\right)$ are shown in Figs. 3 and 4 ; those for $\mathrm{Rb}_{2}\left(\mathrm{TeBr}_{6}\right)$ or $\left(\mathrm{NH}_{4}\right)_{2}\left(\mathrm{TeBr}_{6}\right)$ and $\left[\left(\mathrm{CD}_{3}\right)_{4} \mathrm{~N}\right]_{2}\left(\mathrm{TeBr}_{6}\right)$ were quite analogous to $\mathrm{Cs}_{2}\left(\mathrm{TeBr}_{6}\right)$ and $\left[\left(\mathrm{CH}_{3}\right)_{4} \mathrm{~N}\right]_{2}\left(\mathrm{TeBr}_{6}\right)$, re spectively. Spectra of the hexabromoplatinates are given in Fig. 5. Frequencies of all the observed bands are given in Table III.

Comparisons of spectra at room and low temperatures showed the usual sharpening and small shifts in band positions. Apart from this, the $\mathrm{Rb}$ and $\mathrm{Cs}$ salts changed very little. The other salts each have their own characteristic behavior.

\section{B. Cubic compounds (Rb, Cs, $\left.\mathrm{NH}_{4}\right)_{2}\left(\mathrm{TeBr}_{6}\right.$ )}

The room temperature vibrational data given for these compounds in the literature were reproduced within $\sim 2$ $\mathrm{cm}^{-1} \cdot{ }^{17-23}$ The Raman active lattice mode $\nu_{L 2}$ of $\mathrm{Cs}_{2}\left(\mathrm{TeBr}_{6}\right)$ was seen at $43 \mathrm{~cm}^{-1}$ and Stufkens ${ }^{23}$ also had a weak feature near $\sim 45 \mathrm{~cm}^{-1}$. The IR spectrum ${ }^{20}$ of $\mathrm{Cs}_{2}\left(\mathrm{TeBr}_{6}\right)$ at $\sim 120 \mathrm{~K}$ is in agreement with our results. The new low temperature data (Table III) is in accordance with the absence of phase transitions for $\mathrm{Rb}$ and $\mathrm{Cs}$ salts, whereas new IR bands appeared for $\left(\mathrm{NH}_{4}\right)_{2}\left(\mathrm{TeBr}_{6}\right)$, presumably due to the known phase transitions near 200 K. ${ }^{6,14}$ The assignments given tentatively in Table III follow those of $\mathrm{K}_{2}\left(\mathrm{TeBr}_{6}\right)$ (see Sec. IV C).

The IR active modes $\nu_{4}$ and $\nu_{23}$ both have the same $T_{1 u}$ symmetry and thus may couple. This might explain the peculiar behavior of the band formally assigned as the lattice mode $\nu_{L 3}$. Note that $\nu_{L 3}(\mathrm{Rb}) \leq \nu_{L 3}(\mathrm{Cs})$, even though the mass of rubidium is much less than that of cesium. 


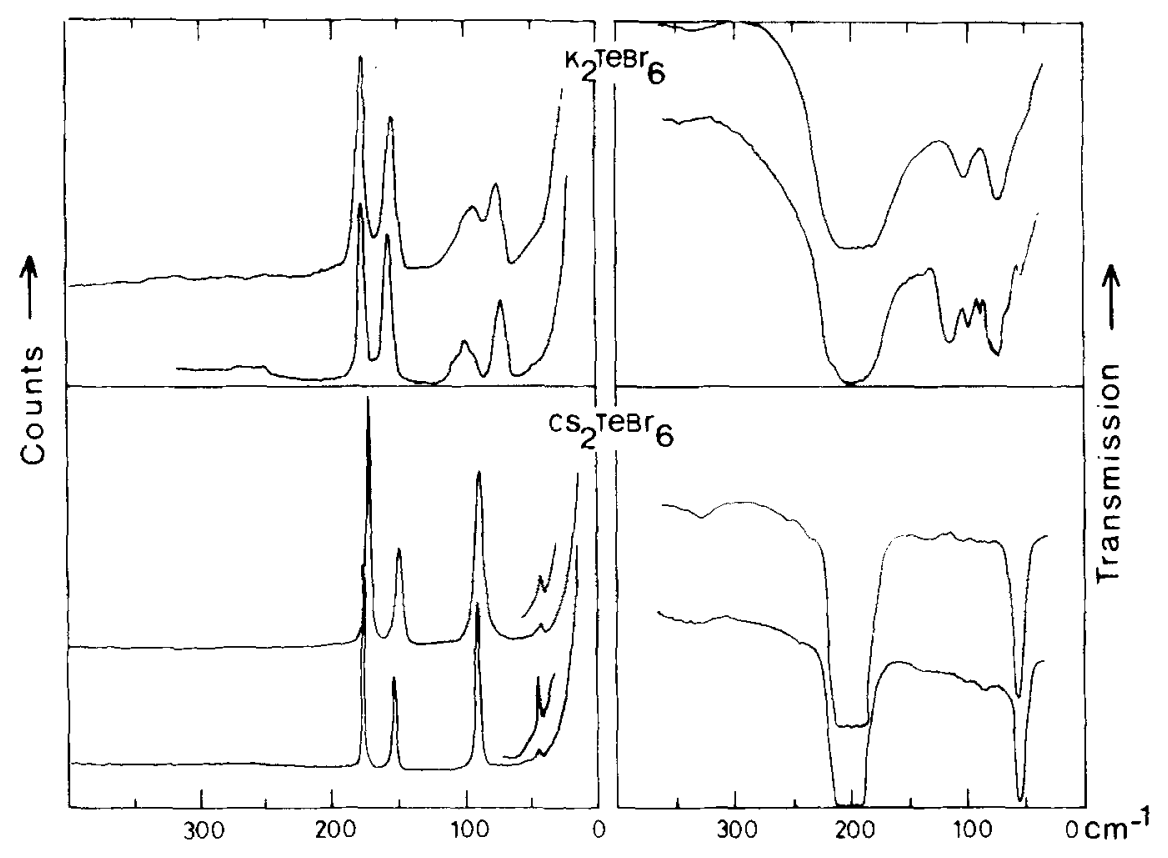

FIG. 3. $\mathrm{K}_{2}\left(\mathrm{TeBr}_{6}\right)$ and $\mathrm{Cs}_{2}\left(\mathrm{TeBr}_{6}\right)$ : Raman (left) and far IR spectra of powder samples, ${ }^{1}$ at room temperature (top) and liquid nitrogen temperature $(\sim 100 \mathrm{~K})$ (bottom). $\mathrm{Rb}_{2}\left(\mathrm{TeBr}_{6}\right)$ and $\left(\mathrm{NH}_{4}\right)_{2}\left(\mathrm{TeBr}_{6}\right)$ looked much like $\mathrm{Cs}_{2}\left(\mathrm{TeBr}_{6}\right)$ except in the IR where $\left(\mathrm{NH}_{2}\right)_{2}\left(\mathrm{TeBr}_{6}\right)$ showed $\nu_{4}$ and $\nu_{6}$ bands at low temperature.

\section{Monoclinic $\mathrm{K}_{2}\left(\mathrm{TeBr}_{6}\right)$}

At room temperature, hardly any noncubic features are present; the IR and Raman spectra have the usual three and four bands, respectively, characteristic of cubic $\mathrm{A}_{2}\left(\mathrm{MX}_{6}\right)$ crystals. This is consistent with the previous results. ${ }^{18-22}$ By cooling, there is a (reversible) gradual sharpening of the bands. The $53 \mathrm{~cm}^{-1} \mathrm{IR}$ band is faintly observable at room temperature, and becomes increasingly distinct at lower temperatures. The 89 and $100 \mathrm{~cm}^{-1}$ IR bands can be weakly discerned around $200 \mathrm{~K}$ and are distinct only below $\sim 120 \mathrm{~K}$. The $\nu_{4}$ band shifts gradually from $\sim 100$ to $110 \mathrm{~cm}^{-1}$ by the cooling from 300 to $100 \mathrm{~K}$. At low temperature $(\sim 120 \mathrm{~K})$, Adams et $a l .{ }^{20}$ observed $\nu_{4}$ at $\sim 113 \mathrm{~cm}^{-1}$ and the bands at 78 and $55 \mathrm{~cm}^{-1}$, but they did not resolve the sharp weak bands at 100 and $89 \mathrm{~cm}^{-1}$.

No low temperature Raman results for $\mathrm{K}_{2}\left(\mathrm{TeBr}_{6}\right)$ have previously been reported. The broad bands at 99 and $92 \mathrm{~cm}^{-1}$ at room temperature (at 100 and $88 \mathrm{~cm}^{-1}$ according to Ref. 21) gradually sharpen into a triplet (111, 103, and $94 \mathrm{~cm}^{-1}$ ), and weak but clearly real bands at 48 and $34 \mathrm{~cm}^{-1}$ appear at $\sim 100 \mathrm{~K}$.

There is an assignment problem with $\nu_{5}$. This mode
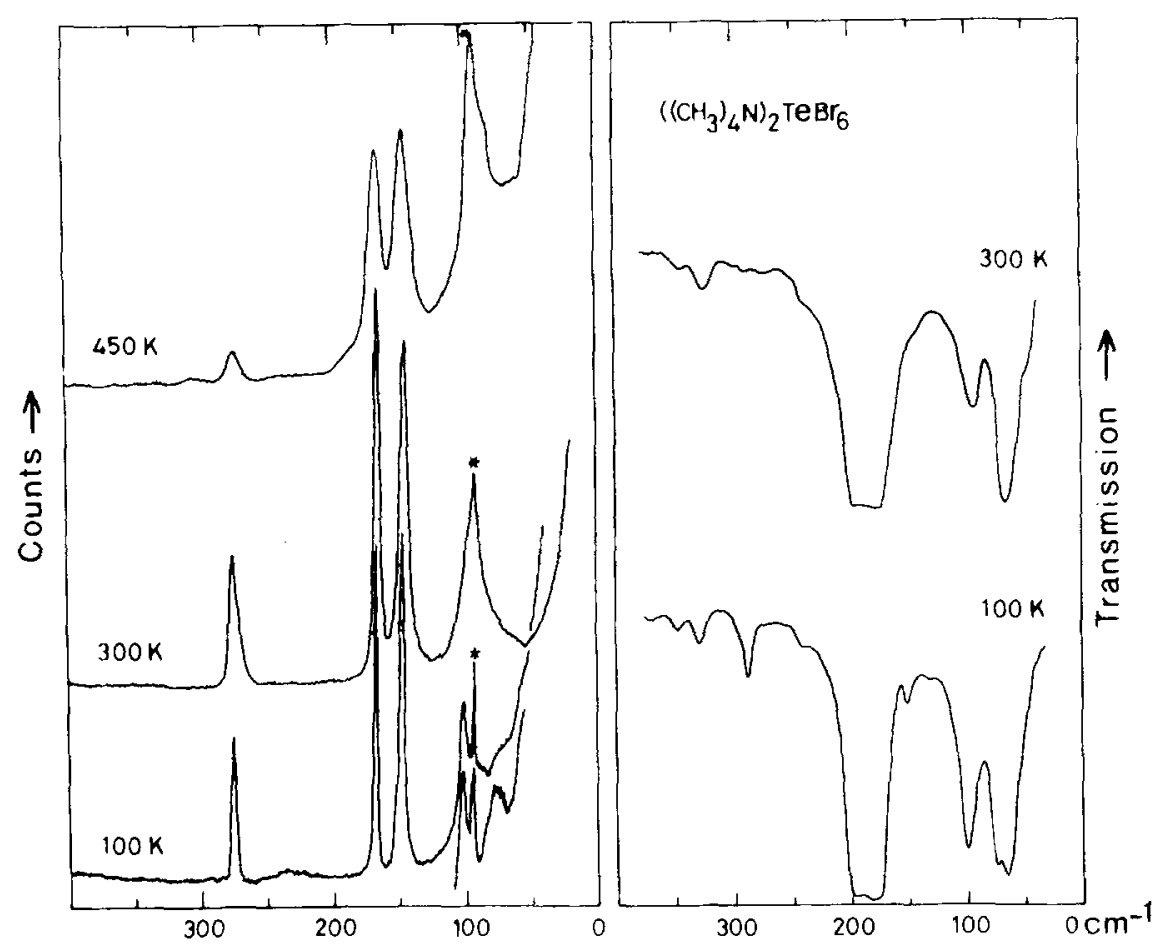

FIG. 4. $\left[\left(\mathrm{CH}_{3}\right)_{4} \mathrm{~N}\right]_{2}\left(\mathrm{TeBr}_{6}\right)$ : Raman (Ieft) and far IR spectra of powder samples ${ }^{1}$ at the indicated temperatures. The spectra of $\left[\left(\mathrm{CD}_{3}\right)_{4} \mathrm{~N}\right]_{2}\left(\mathrm{TeBr}_{6}\right)$ were similar except for having a medium IR band at $380 \mathrm{~cm}^{-1}$ and no $287 \mathrm{~cm}^{-1}$ band at low temperature. The $v_{3} \mathrm{CN}$ symmetric stretching Raman active mode at 752 (hydrogen) and $678 \mathrm{~cm}^{-1}$ (deuterium) proved the identity of the samples and hence that the $275 \mathrm{~cm}^{-1}$ Raman bands are not methyl torsions. A laser plasma line is marked with asterisks. 


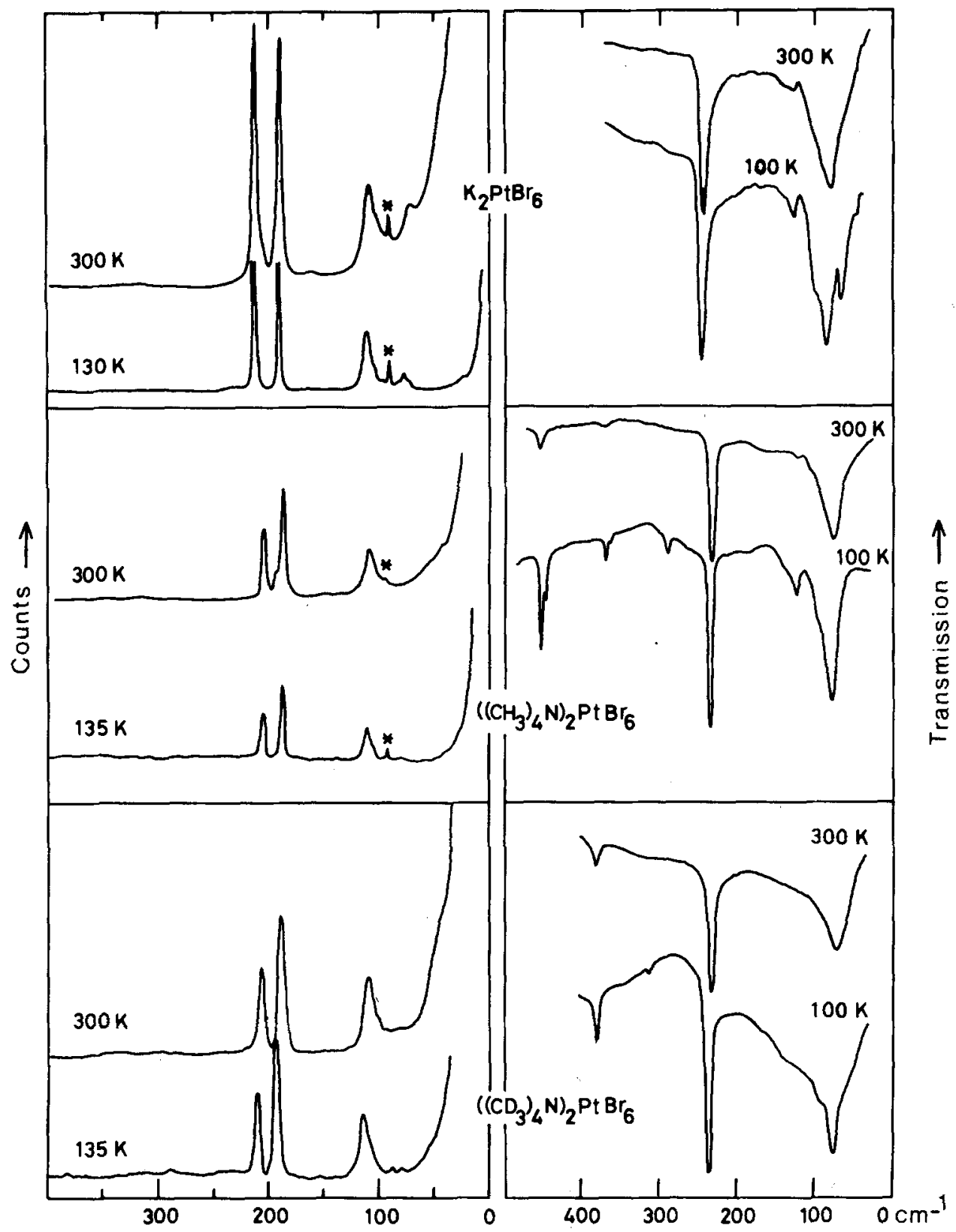

FIG. 5. Raman (left) and far IR spectra of powder samples ${ }^{1}$ of hexabromoplatinates at the indicated temperatures. A laser plasma line is marked with asterisks.

has been observed near $70 \mathrm{~cm}^{-118,22}$ in the Raman spectrum of aqueous solutions of $\left(\mathrm{TeBr}_{6}\right)^{2-}$ and around 90 $\mathrm{cm}^{-1}$ in the $\mathrm{Rb}$ and $\mathrm{Cs}$ salts (Table III). An approximate formula derived by Yost et al. ${ }^{35}$ estimates $\nu_{5}$ of an octahedral $\left(\mathrm{MX}_{6}\right)^{2-}$ ion as $\left[2 / 3\left(\nu_{1}^{2}-\nu_{2}^{2}\right)\right]^{1 / 2}$. Thus, using 177 and $157 \mathrm{~cm}^{-1}$ for $\nu_{1}$ and $\nu_{2}$, respectively, one gets a value of $\nu_{5}=67 \mathrm{~cm}^{-1}$, i.e., near the value in solution.

In $\mathrm{K}_{2}\left(\mathrm{TeBr}_{8}\right)$, Hendra and Zović $\hat{c}^{18}$ identified Raman bands at 90 and $75 \mathrm{~cm}^{-1}$ as $\nu_{5}$ and $\nu_{L 2}$, respectively. Adams and Morris, ${ }^{19}$ on the other hand, assigned $\nu_{5}$ to their $73 \mathrm{~cm}^{-1}$ band but presumed that $\nu_{5}$ and $\nu_{L 2}$ interact due to identical symmetry so that a definite assignment is not possible. Creighton and $\mathrm{Green}^{22}$ took $\nu_{5}$ to be split into bands at 85 and $70 \mathrm{~cm}^{-1}$ due to the monoclinic symmetry. Finally, Donaldson et al. ${ }^{21}$ assigned bands at 100 and $88 \mathrm{~cm}^{-1}$ to $\nu_{5}$, and the $78 \mathrm{~cm}^{-1}$ band was identified with perhaps $\nu_{5}$ or $\nu_{L 2}$.
A consistent explanation appears to be that the bands at 99,92 , and $74 \mathrm{~cm}^{-1}$ contain a mixture of the "modes" $\nu_{5}$ and $\nu_{L 2}$. Hence, the identifications in Table III $\left(\nu_{5}\right.$ $=99$ and $92 \mathrm{~cm}^{-1}$ and $\nu_{L 2}=74 \mathrm{~cm}^{-1}$ ) should not be taken rigorously; we merely estimate this to be the most predominant character of the bands.

The low temperature Raman bands at 48 and $34 \mathrm{~cm}^{-1}$ are assigned to $\nu_{L 1}$, the anion librations. Analogous bands occur in the low temperature phases of $\mathrm{K}_{2}\left(\mathrm{ReCl}_{8}\right)$, $\mathrm{K}_{2}\left(\mathrm{SnCl}_{8}\right), \mathrm{K}_{2}\left(\mathrm{SnBr}_{6}\right)$, and $\mathrm{K}_{2}\left(\mathrm{TeCl}_{8}\right),{ }^{36-40,1}$ e.g., in $\mathrm{K}_{2}\left(\mathrm{SnCl}_{6}\right)$, the (cubic) inactive $T_{1, g}\left(\nu_{L 1}\right)$ rotatory mode of the $\left(\mathrm{SnCl}_{6}\right)^{2-}$ octahedra becomes Raman active in the monoclinic phase $\left(C_{2 h}^{5}\right.$; below $255 \mathrm{~K}$ ) and splits into two bands, observed at 46 and $38 \mathrm{~cm}^{-1}$ at $50 \mathrm{~K}^{37}$ In $\mathrm{K}_{2}\left(\mathrm{SnBr}_{6}\right)$, the bands occur at $\sim 47$ and $\sim 33 \mathrm{~cm}^{-1}$ at 100 $K^{38-40}$ The $\nu_{L 1}$ bands in $\mathrm{K}_{2}\left(\mathrm{ReCl}_{6}\right), \mathrm{K}_{2}\left(\mathrm{SnCl}_{6}\right)$, and $\mathrm{K}_{2}\left(\mathrm{SnBr}_{6}\right)$ have been shown $\mathrm{n}^{36,37,39,40}$ to display "soft 


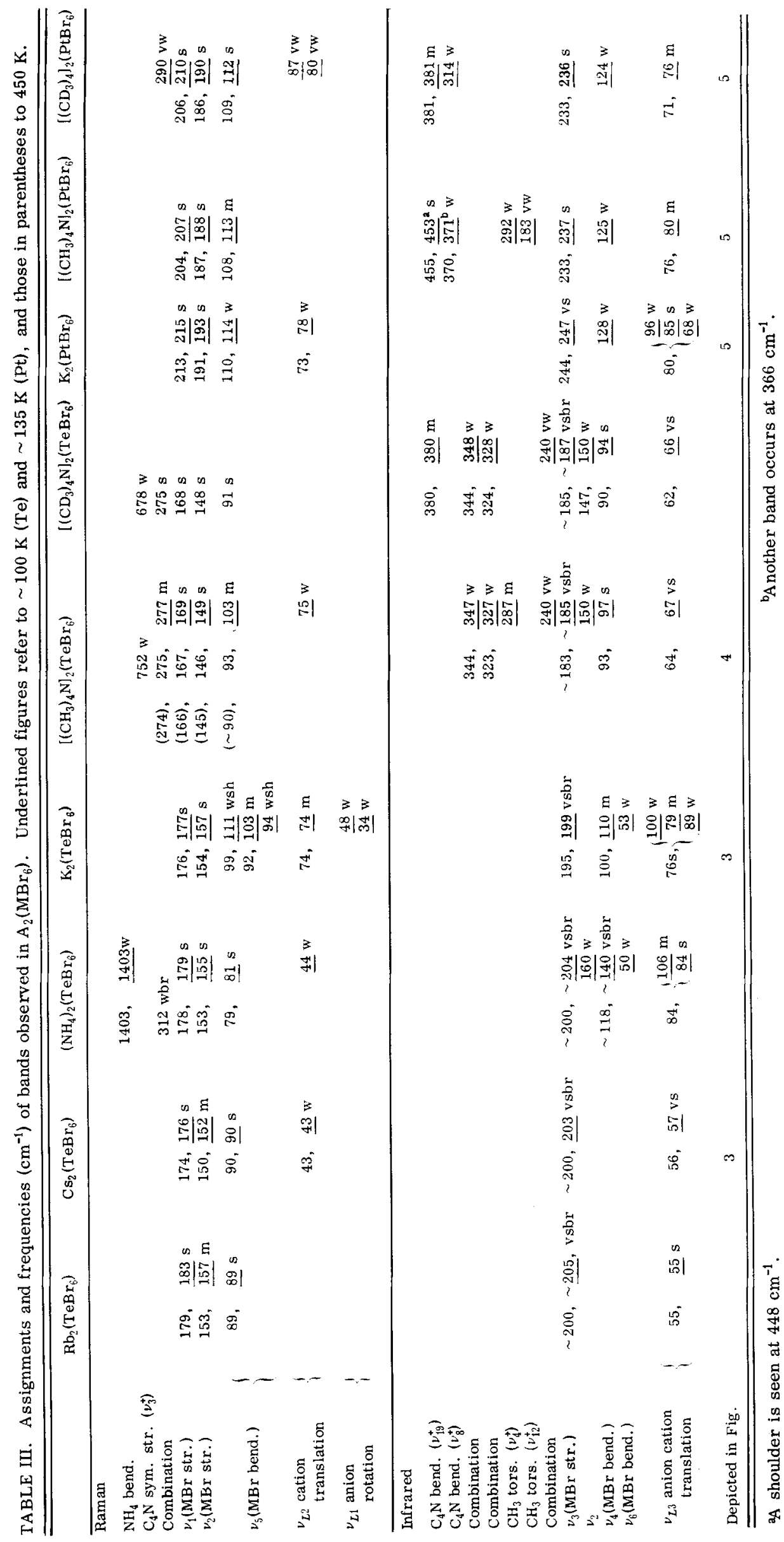

J. Chem. Phys., Vol. 71, No. 6, 15 September 1979 
mode" behavior (i.e., having frequencies which depend markedly on the temperature). It was not possible with our equipment to detect any expected softening of the $\nu_{L 1}$ bands in $\mathrm{K}_{2}\left(\mathrm{TeBr}_{6}\right)$.

At low temperatures, the new IR bands appearing at 100,89 , and $53 \mathrm{~cm}^{-1}$ deserve an explanation. The 53 $\mathrm{cm}^{-1}$ band was assigned as mainly $\nu_{6}$ by Adams et al. ${ }^{20}$ based upon previous force field calculations on $\left.(\mathrm{TeBr})^{2-}\right)^{19}$ The approximate relationship $\nu_{5}=\nu_{6} \sqrt{2}$ gives $\nu_{5}=75 \mathrm{~cm}^{-1}$ using $\nu_{8}=53 \mathrm{~cm}^{-1}$, and this value of $\nu_{5}$ is in reasonable agreement with the solution value of $\sim 70 \mathrm{~cm}^{-1}$. We explain the weak bands at 100 and $89 \mathrm{~cm}^{-1}$ as components of $\nu_{4}$ and $\nu_{L 3}$, these modes being split by the low symmetry (Table I).

In the monoclinic $\mathrm{K}_{2}\left(\mathrm{TeBr}_{6}\right)$ structure, the $\nu_{L 1}$ rotatory modes are Raman allowed and the splitting of the $\nu_{4}$ and $\nu_{L 3}$ IR active modes takes place, already at room temperature (Table I). Hence, it is not possible to decide whether the appearance of the new bands in $\mathrm{K}_{2}\left(\mathrm{TeBr}_{6}\right)$ by cooling is caused by the normal sharpening of bands already weakly present (in conjunction with a gradually inc reasing distortion of the structure) or whether a furthe $r$ phase transition occurs somewhat above $120 \mathrm{~K}$. The latter possibility might well be realized [cf. the five transitions in $\mathrm{K}_{2}\left(\mathrm{PtBr}_{6}\right)$, the four transitions in $\mathrm{K}_{2}\left(\mathrm{ReCl}_{6}\right)^{36}$ and the transition in monoclinic $\mathrm{K}_{2}\left(\mathrm{TeCl}_{6}\right)$ at $\sim 165 \mathrm{~K}^{1}$ ]. The NQR data given by Nakamura et al. ${ }^{6}$ indicated a possible transition near $243 \mathrm{~K}$. Further experiments, like NQR frequency data as a function of temperature, are needed to clarify the situation.

\section{D. $\left[\left(\mathrm{CH}_{3}\right)_{4} \mathrm{~N}\right]_{2}\left(\mathrm{TeBr}_{6}\right)$}

At room temperature, Adams and Morris ${ }^{19}$ identified $\nu_{1}, \nu_{2}, \nu_{3}$, and $\nu_{5}$ modes at $170,148,180$, and $96 \mathrm{~cm}^{-1}$, and the IR bands at 104 and $68 \mathrm{~cm}^{-1}$ were thought to be mixtures of $\nu_{4}$ and $\nu_{L 3}$. These results seem to be essentially correct. We observed the IR bands at 93 and $64 \mathrm{~cm}^{-1}$ and they both shift on deuteration.

Perhaps, the most remarkable observation (Fig. 4) is the Raman band at $275 \mathrm{~cm}^{-1}$. A comparison of the $\left[\left(\mathrm{CH}_{3}\right)_{4} \mathrm{~N}\right]_{2}\left(\mathrm{TeBr}_{6}\right),\left[\left(\mathrm{CD}_{3}\right)_{4} \mathrm{~N}\right]_{2}\left(\mathrm{TeBr}_{6}\right)$, and for example, $\mathrm{Cs}_{2}\left(\mathrm{TeBr}_{5}\right)$ spectra shows that the $275 \mathrm{~cm}^{-1}$ Raman band of the former compounds is not due to the $\left(\mathrm{CH}_{3}\right)_{4} \mathrm{~N}$ ions: If it were a $\left(\mathrm{CH}_{3}\right)_{4} \mathrm{~N}$ internal, it must be a methyl tor sional mode by virtue of its low frequency ${ }^{24}$ and hence it should suffer some deuteration shift, which it does not. Thus, we conclude that the band cannot be a methyl torsion (the observation of the polarized totally symmetric $\mathrm{C}_{4} \mathrm{~N}$ stretching mode $\nu_{3}^{+}$at $752 \mathrm{~cm}^{-1}$ for the hydrogen compound and at $678 \mathrm{~cm}^{-1}$ for the deuterium compound proved the deuteration). On the other hand, if the 275 $\mathrm{cm}^{-1}$ Raman band is a mode characteristic of $\left(\mathrm{TeBr}_{6}\right)^{2-}$, it should be observable in other $A_{2}\left(T_{e B r}\right)$ salts. At first glance, this is not the case. The most reasonable explanation appears to be that the $275 \mathrm{~cm}^{-1}$ band is a second order feature of the internal motion of the $\left(\mathrm{TeBr}_{6}\right)^{2-}$ ion, accidentally enhanced in these compounds. Binary combinations of the modes occurring near 185 and $90 \mathrm{~cm}^{-1}$ seem a likely way to fulfill the requirement of energy conservation $(93+183=276$ and $90+185=275$ $\mathrm{cm}^{-1}$; see Table III). Following these ideas, a very weak band at $312 \mathrm{~cm}^{-1}$ in $\left(\mathrm{NH}_{4}\right)_{2}\left(\mathrm{TeBr}_{6}\right)$ can be explained as a combination of bands at $\sim 200$ and $\sim 118 \mathrm{~cm}^{-1}$. The resonating combination in the tetramethylammonium compounds thus seems to be $\nu_{3}+\nu_{4}$ rather than $\nu_{3}+\nu_{5}$; $\nu_{3}$ and $\nu_{4}$ are odd modes forming even combinations, whereas a combination of $\nu_{3}$ and $\nu_{5}$ is odd and hence is not Raman allowed in a centrosymmetric crystal.

The weak IR features seem to origin from combinations of $\nu_{1}+\nu_{3}\left(344 \mathrm{~cm}^{-1}\right), \nu_{2}+\nu_{3}$ or $\nu_{5}+\nu_{4}\left(323 \mathrm{~cm}^{-1}\right)$, and $\nu_{2}+\nu_{4}\left(240 \mathrm{~cm}^{-1}\right)$, all being of the type even + odd $=$ odd .

The symmetry center of the crystal structure seems to be largely but not entirely conserved at low temperatures: It is difficult to explain the $150 \mathrm{~cm}^{-1}$ weak IR bands as anything except $\nu_{2}$. This applies also for the weak $160 \mathrm{~cm}^{-1}$ band of $\left(\mathrm{NH}_{4}\right)_{2}\left(\mathrm{TeBr}_{6}\right)$. Since the even $\nu_{2}$ mode is IR forbidden under centrosymmetry, these crystals cannot strictly preserve their centrosymmetric structures at low temperatures, at least not on a time scale corresponding to an inf rared experiment even though the time averaged structure as sampled using for example, $\mathrm{x}$-ray diff raction methods might show centrosymmetry. Analoguously, the $\left[\left(\mathrm{CH}_{3}\right)_{4} \mathrm{~N}\right]_{2}\left(\mathrm{PtCl}_{6}\right)$ $\mathrm{X}$-ray crystal structure was shown to be centrosymmetric at room temperature ${ }^{41,8}$ yet the vibrational spectra of the compound clearly indicated weak noncentrosym metry ( $\nu_{2}$ and $\nu_{3}$ were active in both IR and Raman). ${ }^{18}$ The noncentrosymmetry may be caused by a chirality of the tetramethylammonium ions (see Sec. V).

The presence of bands due to combinations in the spectra indicates anharmonicity. Normally, the anharmonicity of crystal modes increases with temperature because the larger population of thermal phonons in a hot crystal leads to enhanced phonon-phonon interaction. In the present case, the intensity of the anharmonicity allowed combination bands decrease with increasing temperature (Fig. 4), so that other effects than phonon populations must play a role. It is thought that the observed increase in anharmonicity at low temperatures might be accounted for by changes in the methyl torsional modes. These changes (Sec. V) in turn affect the $\left(\mathrm{TeBr}_{6}\right)^{2-}$ vibrations because of the close methyl-bromine contacts in the crystal. ${ }^{8}$ In this way, an intensity trend opposite to that normally found can qualitatively be accounted for.

The methyl torsional modes within a $\left[\left(\mathrm{CH}_{3}\right)_{4} \mathrm{~N}\right]_{2}\left(\mathrm{MX}_{6}\right)$ crystal of $F m 3 m$ symmetry are inactive. ${ }^{1}$ The space group symmetry $F d 3 c$ found for $\left[\left(\mathrm{CH}_{3}\right)_{4} \mathrm{~N}\right]_{2}\left(\mathrm{TeBr}_{6}\right)$, on the other hand, allows the methyl torsions to be IR and Raman observable in theory at room temperature ( $\mathrm{Ta}$ ble II), but in practice these bands are too weak and broad to be seen in the spectra at room temperature. We are sure about this because the spectra of the $\left[\left(\mathrm{CH}_{3}\right)_{4} \mathrm{~N}\right]_{2}\left(\mathrm{MB}_{6}\right)$ family of crystals are more easy to interpret than the corresponding hexachlorides. This is because the $\left(\mathrm{MBr}_{6}\right)$ internals generally occur below 250 $\mathrm{cm}^{-1}$, leaving the methyl torsional range around $300 \mathrm{~cm}^{-1}$ clean, whereas these two kinds of modes have similar energies in the hexachlorides. ${ }^{1}$ There is therefore no doubt that the band observed at $287 \mathrm{~cm}^{-1}$ in IR at low temperatures (Table III) is due to a methyl group tor- 
TABLE IV. Calculation of methyl torsional barrier heights in the threefold harmonic potential approximation. The overall moment of inertia of $\left(\mathrm{CH}_{3}\right)_{4} \mathrm{~N}^{+}$and the reduced methyl moment of inertia were taken to be $173 \times 10^{-40}$ and $5.17 \times 10^{-40} \mathrm{~g} \mathrm{~cm}^{2}$ giving an $F$ parameter of $5.46 \mathrm{~cm}^{-1}$.

\begin{tabular}{|c|c|c|c|c|c|c|c|}
\hline \multirow[b]{2}{*}{ Compound } & \multirow{2}{*}{$\begin{array}{l}\text { Band } \\
\left(\mathrm{cm}^{-1}\right)\end{array}$} & \multicolumn{2}{|c|}{$\begin{array}{l}\text { Torsional barrier } \\
2 K / 9\end{array}$} & \multicolumn{2}{|c|}{$\begin{array}{c}\text { Methyl-methyl } \\
\text { interaction } 2 L / 9\end{array}$} & \multicolumn{2}{|c|}{$\overline{\bar{V}}_{3}^{\text {Mathieu barrier }}$} \\
\hline & & $\mathrm{cm}^{-1}$ & $\mathrm{kcal} / \mathrm{mole}$ & $\mathrm{cm}^{-1}$ & $\mathrm{kcal} / \mathrm{mole}$ & $\mathrm{cm}^{-1}$ & $\mathrm{kcal} / \mathrm{mole}$ \\
\hline$\left[\left(\mathrm{CH}_{3}\right)_{4} \mathrm{~N}_{2}\left(\mathrm{TeBr}_{6}\right)\right.$ & 287 & $\cdots$ & $\cdots$ & $\cdots$ & $\cdots$ & 1806 & 5.2 \\
\hline$\left[\left(\mathrm{CH}_{3}\right)_{4} \mathrm{~N}\right]_{2}\left(\mathrm{PtBr}_{6}\right)$ & $\begin{array}{l}292 \\
183\end{array}$ & 1472 & 4.2 & -263 & -0.75 & $\begin{array}{r}1904 \\
792\end{array}$ & $\begin{array}{l}5.4 \\
2.3\end{array}$ \\
\hline$\left[\left(\mathrm{CH}_{3}\right)_{4} \mathrm{~N}_{2}\left(\mathrm{PtCl}_{6}\right)\right.$ & $\begin{array}{l}298^{2} \\
228^{\mathrm{a}}\end{array}$ & 1620 & 4.6 & -187 & -0.54 & $\begin{array}{l}1965 \\
1192\end{array}$ & $\begin{array}{l}5.6 \\
3.4\end{array}$ \\
\hline$\left(\mathrm{CH}_{3}\right)_{4} \mathrm{~N} \mathrm{NiCl}_{3}$ & $\begin{array}{l}320^{\mathrm{b}} \\
291^{\mathrm{b}}\end{array}$ & 1994 & 5.7 & -90 & -0.28 & $\begin{array}{l}2236 \\
1880\end{array}$ & $\begin{array}{l}6.4 \\
5.4\end{array}$ \\
\hline
\end{tabular}

Reference 1(b).

${ }^{\mathrm{b}}$ Reference 44.

sional mode. We cannot exclude that the reason for the enhanced IR intensity at low temperatures might be a possible occurrence of a phase transition like the one observed in $\left[\left(\mathrm{CH}_{3}\right)_{4} \mathrm{~N}\right]_{2}\left(\mathrm{TeCl}_{6}\right),{ }^{1}$ but the re was no abrupt change in the spectra at any particular temperature, so if any phase change is involved, it is a quite gradual one.

\section{E. $\mathrm{K}_{2}\left(\mathrm{PtBr}_{6}\right)$}

The room temperature spectra (Fig. 5) are in accordance with the cubic structure. Assigning the spectra presented no problem except for the $\nu_{4}$ mode. Adams et al. ${ }^{25,28}$ assigned their $78 \mathrm{~cm}^{-1}$ IR band to $\nu_{4}$, whereas Hiraishi ${ }^{26}$ and Hendra ${ }^{29}$ took $\nu_{4}=90 \mathrm{~cm}^{-1}$. In a more recent paper, Adams ${ }^{31}$ identified a band at $82 \mathrm{~cm}^{-1}$ as due to $\nu_{4}$ as well as $\nu_{L 3}$. On the other hand, Debeau ${ }^{27}$ held $\nu_{4}$ to be unobserved due to accidental weakness and $\nu_{L 3}$ $=85 \mathrm{~cm}^{-1}$. Inspection of our temperature dependent IR spectra of $\mathrm{K}_{2}\left(\mathrm{PtBr}_{6}\right)$ ( $\mathrm{Fig}$. 5) in comparison to the tetramethylammonium compounds shows that $\nu_{4}$ is in fact very weak at room temperature but can be observed near $125 \mathrm{~cm}^{-1}$ at $\sim 100 \mathrm{~K} . \nu_{4}$ was seen at $146 \mathrm{~cm}^{-1}$ in $\left(\mathrm{NH}_{4}\right)_{2}\left(\mathrm{PtBr}_{6}\right)^{27.30}$ and an average value of $134 \mathrm{~cm}^{-1}$ was given for four $\left(\mathrm{R}-\mathrm{NH}_{3}\right)_{2}\left(\mathrm{PtBr}_{6}\right)$ salts $^{42}(\mathrm{R}=$ methyl, ethyl, $n$-propyl, and isopropyl). Finally, the cation mass dependence of the $\sim 80 \mathrm{~cm}^{-1}$ band (Table III) solves the assignment ambiguity: $\nu_{4}=\sim 128$ and $\nu_{L 3}=\sim 80 \mathrm{~cm}^{-1}$ in $\mathrm{K}_{2}\left(\mathrm{PtBr}_{6}\right)$ at room temperature. Force field calculations and correlations of the bonding in the $\left(\mathrm{PtBr}_{6}\right)^{2-}$ ion $^{26,28,29,43}$ are of course more or less meaningless when based on erroneous assignment of $\nu_{4}$. Therefore, the calculations by Debeau and Poulet ${ }^{30}$ should be considered the most reliable results to date on $\left(\mathrm{PtBr}_{6}\right)^{2-}$.

Careful inspection of the low temperature spectra of $\mathrm{K}_{2}\left(\mathrm{PtBr}_{6}\right)$ shows indications of a decrease in crystal symmetry: The band shapes are not all symmetrical. $\nu_{5}, \nu_{L 2}$, and $\nu_{L 3}$ seem to lose their threefold degeneracy, becoming split into site symmetry components. However, if we did not know in advance from the NQR and DT A results ${ }^{13,14}$ that transitions to lower symmetric phases occurred, we would not have been able to make it out with certainty. It must be concluded that the influence of the structural changes associated with the phase transitions at $169,143,137$, and perhaps $105 \mathrm{~K}$ on the vibrational spectra is very modest.

\section{F. $\left[\left(\mathrm{CH}_{3}\right)_{4} \mathrm{~N}\right]_{2}\left(\mathrm{PtBr}_{6}\right)$}

Knowing the fundamental frequencies of the $\left(\mathrm{PtBr}_{6}\right)^{2-}$, $\left[\left(\mathrm{CH}_{3}\right)_{4} \mathrm{~N}\right]^{+}$, and $\left[\left(\mathrm{CD}_{3}\right)_{4} \mathrm{~N}\right]^{+}$ions from the literature, the spectra (Fig. 5) were easily assigned (Table III). The room temperature spectra yield no indication of any deviation from a cubic structure. At lower temperatures, methyl torsional bands gradually (and reversibly) appear, excluding a cubic $F m 3 m$ structure. but not the $F d 3 c$ structure (Table II). Like for $\left[\left(\mathrm{CH}_{3}\right)_{4} \mathrm{~N}\right]_{2}\left(\mathrm{TeBr}_{6}\right)$ [and $\left(\mathrm{CH}_{3}\right)_{4} \mathrm{NNiBr}_{3}{ }^{44}$, the sharpening of the methyl torsional bands is the more pronounced the lower the temperature, so that the possibility of the occurrence of phase transitions cannot be answered without further studies.

\section{METHYL ROTATIONAL DISORDER IN $\left[\left(\mathrm{CH}_{3}\right)_{4} \mathrm{~N}\right]_{2}\left(M X_{6}\right)$ SALTS}

In a thermodynamic study, Pitzer ${ }^{45}$ concluded that the methyl groups in the tetramethylmethane molecule [neopentane, isoelectronic with $\left.\left(\mathrm{CH}_{3}\right)_{4} \mathrm{~N}^{+}\right]$are prevented from rotating freely by a potential barrier of about $4.2 \mathrm{kcal} /$ mole $\left(\sim 1470 \mathrm{~cm}^{-1}\right)$. More recent investigations using various experimental methods $s^{46-48}$ have confirmed this order of magnitude. The tetramethylammonium ion appears to have a higher barrier, around $6-7 \mathrm{kcal} / \mathrm{mole}$, in its chloride, bromide, iodide, and hexafluorosilicate salts. ${ }^{49-55}$

Using the observed torsional frequencies and the formulas derived in previous papers, ${ }^{46,47}$ approximate barrier heights against methyl torsion can be estimated (Table IV). Here, a harmonic approximation to a threefold periodic potential was assumed, ${ }^{47}$ and the eigenvalue $s$ parameters of the Mathieu equation were taken from Ref. 56. The approximation of a threefold barrier can be questioned but seems not to be too unreasonable. ${ }^{53}$ From Table IV, average barrier heights of the order of 4 to $5 \mathrm{kcal} / \mathrm{mole}$ are obtained. With such barrier heights, the methyl groups will largely be confined to restricted torsional oscillations around their $\mathrm{C}-\mathrm{N}$ axes, and will not be pseudo-freely rotating. This point was not adequately stressed in our previous papers, ${ }^{16.42}$ which considered the freezing out of either "essentially free" methyl rotation or some kind of methyl group disordering as explanations for the gradual appearance of 


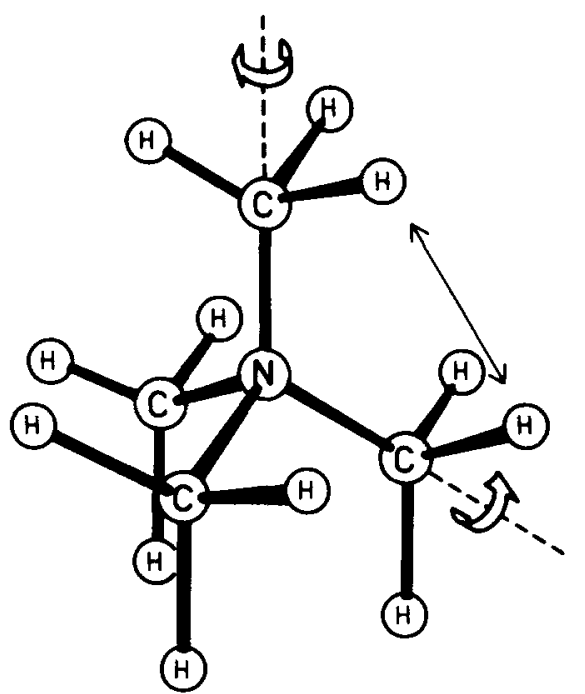

FIG. 6. The tetramethylammonium ion in the staggered conformation. Arrows indicate how small rotations increase the nonbonded intermethyl $\mathrm{H}-\mathrm{H}$ distance.

methyl torsional bands at lower temperatures. The barrier heights in Table IV show that this explanation must be modified: The methyl groups do not perform essentially free rotation even at room temperature $(k T=\sim 0.6 \mathrm{kcal} / \mathrm{mole}$ at $300 \mathrm{~K})$.

Consider a physical "ball and stick" model of the tetramethylammonium ion (Fig. 6). The charge distribution within the ion presumably leaves the hydrogens somewhat positive such that nonbonded hydrogen-hydrogen repulsions can be expected from one methyl group to the other (intermethyl $\mathrm{H}-\mathrm{H}$ distance $=\sim 2.5 \AA$ ). This is the physical basis for the torsional potential barrier in the isolated ion. From the model or Fig. 6, it can be seen that the two high-symmetric staggered and eclipsed conformations of the ion (both having $T_{d}=\overline{4} 3 \mathrm{~m}$ symmetry) are unstable from the point of view of minimizing the nonbonded intermethyl $\mathrm{H}-\mathrm{H}$ repulsions. Starting from the all-staggered conformation, it is found that if the methyl groups are rotated slightly in the same sense (i.e., all clockwise or all counterclockwise around the $\mathrm{C}-\mathrm{N}$ bond), then all the nonbonded intermethyl $\mathrm{H}-\mathrm{H}$ distances increase. A minimum in the potential energy probably occurs near a rotation by $\sim 10^{\circ} 57$ from the staggered conformation (a $60^{\circ}$ rotation would create the eclipsed conformation). The symmetry of the ion in the potential energy minimum conformation is $T=23$. Hence, enantiomorphism occurs.

The potential barrier between "right-handed" and "left-handed" conformations seems to be quite small. This means that at room temperature there is probably an essentially free rotatory oscillation within $\pm 20^{\circ}$ from the staggered conformation. Furthermore, a certain proportion of the ions probably have one of its methyl groups in the eclipsed conformation, since (as the model or Fig. 6 shows) if three methyls in the ion are staggered, then the fourth appears to be quite stable as eclipsed. A similar conclusion has been obtained quantitatively for the neo-pentane molecule. ${ }^{58}$ The eclipsed methyl group can of course be any of the four ones.
Hence, we have several possible methyl-orientational disordering mechanisms in tetramethylammonium crys tals. We expect that this disorder smears out the methyl torsional bands and breaks the crystal translational symmetry, so that phonons from throughout the Brillouin zone become weakly spectroscopically active. The bands may become so broad that they disappear in the background. As the crystal is cooled, the thermal motion is slowed down, gradually producing clusters of higher order and giving the observed reversible sharpening of the methyl torsional bands. A variety of increasingly ordered phases may in principle be formed. Phase transitions have indeed been observed in the majority of the examined tetramethylammonium compounds: in hexahalometallates, ${ }^{1,59}$ trihalometallates, ${ }^{44,60}$ hexahydrohexaborate, ${ }^{61}$ chlorate, ${ }^{62}$ and in the chloride. ${ }^{52,63-66}$

\section{CONCLUSIONS}

It appears from this study that it is possible to observe and detect phase transitions in $\mathrm{A}_{2}\left(\mathrm{MX}_{6}\right)$ crystals using the method of variable temperature vibrational spectroscopy. However, in several cases $\left[\left(\mathrm{NH}_{4}\right)_{2}\left(\mathrm{TeBr}_{6}\right)\right.$, $\mathrm{K}_{2}\left(\mathrm{TeBr}_{6}\right)$, and $\left.\mathrm{K}_{2}\left(\mathrm{PtBr}_{6}\right)\right]$, the effects observed were weak and it must be concluded that transitions exist [like those in $\mathrm{K}_{2}\left(\mathrm{PtBr}_{6}\right)$ ] which produce very little change in the spectra.

For the tetramethylammonium compounds studied, the possibility of the occurrence of methyl rotational orderdisorder type transitions is quite realistic. Other methods, like NQR, DTA, etc. are needed to describe the situation in detail.

\section{ACKNOWLEDGMENT}

The author is very grateful to the Technical University of Denmark for the economic support received.

${ }^{1}$ (a) R. W. Berg, F. W. Poulsen, and N. J. Bjerrum, J. Chem. Phys. 67, 1829 (1977); (b) R. W. Berg, J. Chem. Phys. 69, 1325 (1978).

${ }^{2}$ I. D. Brown, Can. J. Chem. 42, 2758 (1964).

${ }^{3}$ A. K. Das and I. D. Brown, Can. J. Chem. 44, $939(1966) ;$ 47, 4288 (1969); L. M. Manojlovic, Chem. Abstr. 52, 2494 (1958).

${ }^{4}$ K. W. Bagnal, R. W. M. D'Eye, and J. H. Freeman, J. Chem. Soc. 1955, 3959 .

${ }^{5}$ J. E. Fergusson and P. F. Heveldt, Aust. J. Chem. 27, 661 (1974).

${ }^{6}$ D. Nakamura, K. Ito, and M. Kubo, J. Am. Chem. Soc. 84, 163 (1962).

${ }^{7}$ T. C. Gibb, R. Greatrex, N. N. Greenwood, and A. C. Sarma, J. Chem. Soc. A 1970, 212.

${ }^{8} \mathrm{R}$. W. Berg and K. Nielsen, Acta Chem. Scand. (accepted) and unpublished results.

${ }^{9}$ R. H. Busch, E. E. Galloni and C. R. Haitz, Struct. Rep. 15, 160 (1951); A. G. Sharpe, J. Chem. Soc. 1853, 4177.

${ }^{10}$ D. H. Brown, K. R. Dixon, C. M. Livingston, R. H. Nuttall, and D. W. A. Sharp, J. Chem. Soc. A 1867, 100.

${ }^{11}$ H. D. Grundy and I. D. Brown, Can. J. Chem. 48, 1151 (1970).

${ }^{12}$ D. Nakamura, Y. Kurita, K. Ito, and M. Kubo, J. Am. Chem. Soc. 82, $5783(1960)$.

${ }^{13}$ H. M. van Driel, M. Wiszniewska, B. M. Moores, and R. L. A rmstrong, Phys. Rev. B 6, 1596 (1972); R. L. Armstrong, J. Magn. Reson. 20, 214 (1975). 
${ }^{14} \mathrm{~K}$. Rössler and J. Winter, Chem. Phys. Lett. 48, 566 (1977).

${ }^{15}$ M. Wiszniewska and R. L. Armstrong, Can. J. Phys. 61, 781 (1973).

${ }^{16} \mathrm{D}$. Nakamura and M. Kubo, J. Phys. Chem. 68, 2989 (1964).

${ }^{17}$ N. N. Greenwood and B. P. Straughan, J. Chem. Soc. A 1066,962 .

${ }^{18} \mathrm{P}$. J. Hendra and $\mathrm{Z}$. Jovic, J. Chem. Soc. A 1988, 600.

${ }^{19}$ D. M. Adams and D. M. Morris, J. Chem. Soc. A 1967, 2067.

${ }^{20}$ D. M. Adams, J. D. Findlay, M. C. Coles, and S. J. Payne, J. Chem. Soc. Dalton Trans. 1976, 371.

${ }^{21}$ J. D. Donaldson, S. D. Ross, J. Silver, and P. J. Watkiss, J. Chem. Soc. Dalton Trans. 1975, 1980.

${ }^{22} \mathrm{~J}$. A. Creighton and J. H. S. Green, J. Chem. Soc. A 1968, 808.

${ }^{23}$ D. J. Stufkens, Rec. Trav. Chim. 89, 1185 (1970).

${ }^{24}$ R. W. Berg, Spectrochim. Acta Part A 34, 655 (1978).

${ }^{25}$ D. M. Adams and H, A. Gebbie, Spectrochim. Acta 19,925 (1963).

${ }^{26} \mathrm{~J}$. Hiraishi, I. Nakagawa, and T. Shimanouchi, Spectrochim. Acta 20, 819 (1964).

${ }^{27}$ M. Debeau and M. Krauzman, C. R. Acad. Sci. Ser. B 264, 1724 (1967).

${ }^{28}$ D. M. Adams and D. M. Morris, J. Chem. Soc. A 1967, 1666.

${ }^{29}$ P. J. Hendra, Spectrochim. Acta Part A 23, 2871 (1967); P. J. Hendra and P. J. D. Park, Spectrochim. Acta Part A 23, 1635 (1967).

${ }^{30} \mathrm{M}$. Debeau and H. Poulet, Spectrochim. Acta Part A 25, 1553 (1969).

${ }^{31}$ D. M. Adams and S. J. Payne, J. Chem. Soc. Dalton Trans. 1974, 407.

${ }^{32}$ D. Breitinger, G. Bauer, W. Haegler, L. Emmert, and W. Kress, Proceedings of the Sixth International Conference on Raman Spectroscopy, edited by E. D. Schmid, R. S. Krishnan, W. Kiefer, and H. W. Schrötter (Heyden, London, 1978), Vol. II, p. 318.

${ }^{33}$ A. Ries, Z. Krystallogr. 49, 513 (1911).

${ }^{34} \mathrm{H}$. Marshall, Inorganic Syntheses (McGraw-Hill, New York, 1946), Vol. II, p. 189.

${ }^{35}$ D. M. Yost, C. C. Steffens, and S. T. Gross, J. Chem. Phys. 2, 311 (1934).

${ }^{36}$ G. P. O'Leary and R. G. Wheeler, Phys. Rev. B 1, 4909 (1970), and references therein.

${ }^{37}$ J. Pelzl, P. Engels, and R. Florian, Phys. Status Solidi B 82, 145 (1977); J. Winter, K. Rössler, J. Bolz, and J. Pelzl, Phys. Status Solidi B 74, 193 (1976).

${ }^{38} \mathrm{~J}$. W. Anthonsen, Acta Chem. Scand. Ser. A 28, 974 (1974).

${ }^{39}$ B. I. Swanson, Phys. Status Solidi A 47, K95 (1978).

${ }^{40} \mathrm{~J}$. Pelzl (personal communication).
${ }^{41}$ R. W. Berg and I. Søtofte, Acta Chem. Scand. Ser. A 32, 241 (1978).

${ }^{42}$ J. B. Perison and W. B. White, Spectrochim. Acta Part A 33, 487 (1977).

${ }^{43}$ P. Labonville, J. R. Ferraro, M. C. Wall, S. M. C. Basile, and L. J. Basile, Coord. Chem. Rev. 7, 257 (1972).

${ }^{44}$ R. W. Berg and S. Skaarup, J. Phys. Chem. Solids 39, 1193 (1978).

${ }^{45}$ K. Pitzer, J. Chem. Phys. 5, 473 (1938); Discuss. Faraday Soc. 10, 66 (1951).

${ }^{46}$ J. R. Durig, S. M. Craven, and J. Bragin, J. Chem. Phys. 52, 2046 (1970).

${ }^{47}$ S. Weiss and G. E. Leroi, Spectrochim. Acta Part A 25, 1759 (1969).

${ }^{48} \mathrm{C}$. I. Ratcliffe and T. C. Waddington, J. Chem. Soc. Faraday Trans. 2 72, 1821 (1976).

${ }^{49} \mathrm{~J}$. Dufourcq and B. Lemanceau, J. Chim. Phys. 67, $9(1970)$.

${ }^{50}$ M. Mahajan and B. D. N. Rao, J. Phys. Chem. Solids 33, 2191 (1972).

${ }^{51} \mathrm{~S}$. Albert, H. S. Gutowsky, and J. A. Ripmeester, J. Chem. Phys. 66, 3672 (1972).

${ }^{52}$ A. A. V. Gibson and R. E. Raab, J. Chem. Phys. 57, 4688 (1972).

${ }^{53} \mathrm{C}$. I. Ratcliffe and T. C. Waddington, J. Chem. Soc. Faraday Trans. 2 72, 1935 (1976).

${ }^{54} \mathrm{H}$. Rager and A. Weiss, Z. Phys. Chem. NF 93, 299 (1974).

${ }^{55} \mathrm{H}$. Rager and A. Weiss, Ber. Bunsenges. Phys. Chem. 82, 535 (1978).

${ }^{56}$ J. R. Durig, M. S. Craven, and W. C. Harris, Vibrational Spectra and Structure, edited by J. R. Durig (M. Dekker, New York, 1972), Vol. 1, p. 73.

${ }^{57}$ In neo-pentane, a minimum near a rotation of $\sim 7^{\circ}$ has been found numerically by an empirical force field [s. Melberg and Kj. Rasmussen (to be published)].

${ }^{58}$ E. N. Lassetre and L. B. Dean, J. Chem. Phys. 17, 317 (1949).

${ }^{59}$ W. von der Ohe, J. Chem. Phys. 63, 2949 (1975).

${ }^{60}$ P. S. Peercy, B. Morosin, and A. G. Samara, Phys. Rev. B 8, 3378 (1973).

${ }^{61}$ R. Schaeffer, Q. Johnson, and G. S. Smith, Inorg. Chem. 4, 917 (1965).

${ }^{62}$ T. Kiichi, M. Nomoto, N. Nakamura, and H. Chihara, Phys. Status Solidi A 41, K17 (1977).

${ }^{63}$ S. -S. Chang and E. F. Westum, J. Chem. Phys. 36, 2420 (1962).

${ }^{64}$ M. Stammler, J. Inorg. Nucl. Chem. 29, 2203 (1967).

${ }^{65} \mathrm{~J}$. Dufourcq, Y. Haget-Bouillaud, N. B. Chanh, and B. Lemanceau, Acta Crystallogr. Sect. B 28, 1305 (1972).

${ }^{66}$ C. W. F. T. Pistorius and A. A. V. Gibson, J. Solid State Chem. 8, 126 (1973). 